\title{
New moldavites from SW Poland
}

\author{
TOMASZ BRACHANIEC, KRZYSZTOF SZOPA and ŁUKASZ KARWOWSKI
}

Department of Geochemistry, Mineralogy and Petrography; Faculty of Earth Science; University of Silesia; Będzińska Str. 60, PL-41-200 Sosnowiec, Poland.

E-mails: tomasz.brachaniec@o2.pl,krzysztof.szopa@us.edu.pl,lukasz.karwowski@us.edu.pl.

\begin{abstract}
:
Brachaniec, T., Szopa, K. and Karwowski, Ł. 2016. New moldavites from SW Poland. Acta Geologica Polonica, 66 (1), 99-105. Warszawa.

Four newly discovered moldavites from the East and West Gozdnica pits, SW Poland, are characterized. All specimens, including other four, reported earlier, are from Upper Miocene fluvial sediments of the Gozdnica Formation. Their weight varies between 0.529 and $1.196 \mathrm{~g}$. The moldavites are bottle green in colour and have bubbles and inclusions of lechatelierite. Low degree of corrosion suggests short river transport, apparently eastward from Lusatia.
\end{abstract}

Key words: Moldavites; Tektites; Ries; Fluvial transport; Miocene; Poland.

\section{INTRODUCTION}

Large impact craters are relatively rare in geological record on the Earth. All over the world only 164 crater structures are above $1 \mathrm{~km}$ in diameter and only 40 with with more than $20 \mathrm{~km}$ in diameter (Earth Impact Database). The most notable features of such big impacts are significant pressure and temperature caused by extraterrestrial body fall. In some cases, impact may lead to glass production, which is named tektite. The distribution and chemical features of impact glasses are the most diagnostic features of the cosmic body impacts. Tektites are distal ejecta type deposits, next to three other impact melt products (Osinski 2003): (1) crystalline melt bodies in the impact structure, (2) glassy clasts in melt-bearing breccias or suevite, and (3) injection dykes in the crater. These different types of glasses form during the shock melting phase of target. Impact melt glasses resemble a terrestrial volcanic glass in appearance. There are three properties, which can be used to distinguish between the impact and terrestrial types of glasses: (1) the impact glass has a chemical composition of one lithology or mixture of different rock types that are present in the source basement (Dence 1971), (2) it is characterized by the presence of lechatelierite (Stöffler 1984), and (3) it has inclusions of shocked minerals (Engelhardt 1972). Characteristic shapes of tektites result from three stages of processes (Baker 1963): (1) the cooling of molten terrestrial material, (2) the flight of tektites through the atmosphere (however this stage did not occur in most of the tektites) and (3) emplacement on Earth's surface, when geochemical processes, like redeposition or weathering, finally influence the morphology of tektites.

Up to now, only four tektite strewnfields are recognized (Koeberl 2007 and references therein): Central European, North American, Australasian and Ivory Coast. It seems that additional data on new tektites distribution areas are very important to better understand the impact geology. 
The European tektites (moldavites) became the subject of scientific research in the late $18^{\text {th }}$ century. In the 1960s, it was confirmed that moldavites are distributed over three specific areas: the Czech Republic (Bohemia, Moravia and near Cheb), Lusatia (SE Germany) and northern Austria (Trnka and Houzar 2002, and references therein). Until now, these tektites have been the subject of numerous geochemical, sedimentological and physical investigations (e.g., Knobloch et al. 1981, 1983; Engelhardt et al. 1987, 2005; Koeberl et al. 1988; Lange 1995; Meisel et al. 1997; Stöffler et al. 2002; Skála and Čada 2003; Ǩanda et al. 2008; Buchner and Schmieder 2009; Žák et al. 2012; Glass and Simonson 2013). Moldavites source impact structure is the Nördlinger Ries crater in southern Germany. The crater is $24 \mathrm{~km}$ in diameter and is Miocene in age (14.74 $\pm 0.20 \mathrm{Ma}$; Buchner et al. 2013). The Ries crater, together with the smaller, Steinheim crater, situated c. $24 \mathrm{~km}$ west of it, were probably formed as a result of binary asteroid fall (Artemieva et al. 2002). These tektites were produced by a melting of the Upper Freshwater Molasse (Meisel et al. 1997; Trnka and Houzar 2002; Řanda et al. 2008; Magna et al. 2011; Žák et al. 2012), composed mainly of quartz sand with feldspars, carbonate lenses (dolomite) and clay layers. According to Artemieva et al. (2002) the total mass of created moldavites might be up to $10^{10} \mathrm{~kg}$. Brachaniec et al. $(2014,2015)$ described a new moldavite distribution area in SW Poland. In this paper, based on new finds, their size, shape and chemical features are presented and discussed.

\section{LOCALITIES AND GEOLOGICAL SETTINGS}

New specimens of moldavites were found in the East and West Gozdnica sandpits, near the town of Iłowa, in SW Poland. The West Gozdnica sandpit is situated c. $100 \mathrm{~m}$ to the west of the East Goydnica pit (Textfig. 1A).

\section{The East Gozdnica sandpit}

In this open pit mine (Text-fig. 1B), sand and gravel are exploited as a preliminary substratum for grout production and clay sediments for the local ceramic factories. The exposed Neogene sequence is c. $30 \mathrm{~m}$ thick. The oldest sediments are represented by muds with coal detritus of the Mużakowa Formation and are overlain by the "Henryk" brown coal layer (Dyjoret al. 1992, 1998; Piwocki et al. 2004; Żelaźniewicz et al. 2011). The coal layer is followed by the Poznan Formation, which is represented by grey, green, blue and white loam, mud and clay. The youngest sediments are fluvial sands with gravel of the Gozdnica Formation, which yielded the moldavites. The gravel of the Gozdnica Formation is composed mostly of quartz with sharp edges, with grains between 0.5 and $5 \mathrm{~cm}$ in diameter. The sand is mainly yellow to grey in colour. Sporadically the Gozdnica Formation contains clay lenses and fossilized wood. The repeated changes in the sedimentary conditions of the formation are visible; coarse and poorly sorted sands with gravel embedded within fine-grained sand and sandy silt indicate low-energy sedimentation, presumably in river meanders (Stachurska et al. 1971). The Gozdnica Formation is dated to the Late Miocene - Pannonian (Stachurska et al. 1971; Dyjor et al. 1992, 1998; Sadowska 1992; Piwocki and Ziembińska-Tworzydło 1997; Szynkiewicz 2011). According to Baraniecka (1991) this formation can be correlated to uppermost Pliocene sands of the Różce borehole.

\section{The West Gozdnica sandpit}

The West Gozdnica pit mine has been abandoned for more than ten years. The bottom of the pit was flooded, thus the lowermost part of the sequence is no longer exposed; only the Poznań and Gozdnica formations are still accessible. The total thickness of the accessible sequence is c. $25 \mathrm{~m}$.

\section{METHODOLOGY}

During the field works, 3 and $5 \mathrm{~mm}$ sieves were used. In the East Gozdnica sandpit, after sieving c. 1.5 tones of the sediments, three moldavites were found. In case of the West Gozdnica sandpit, one tektite from c. 0.5 tone of sieved sediment was collected. The tektite morphologies were studied under FET Philips 30 electron microscope (15 kV and $1 \mathrm{nA})$ at the Faculty of Earth Sciences, University of Silesia, Sosnowiec, Poland. Microprobe analyses of main elements were conducted in the Inter-Institutional Laboratory of Microanalyses of Minerals and Synthetic Substances, Warsaw, using CAMECA SX-100 electron microprobe. The analytical conditions were: acceleration voltage $15 \mathrm{kV}$, beam current $20 \mathrm{nA}$, counting time $4 \mathrm{~s}$ for peak and background, beam diameter $1 \mathrm{~mm}$. The studied material is stored in the Museum of the Faculty of Earth Sciences, University of Silesia, number WNOZ/Mt/89.

\section{RESULTS}

All found moldavites were chaotically distributed in the sediments of the Gozdnica Formation. From the East 

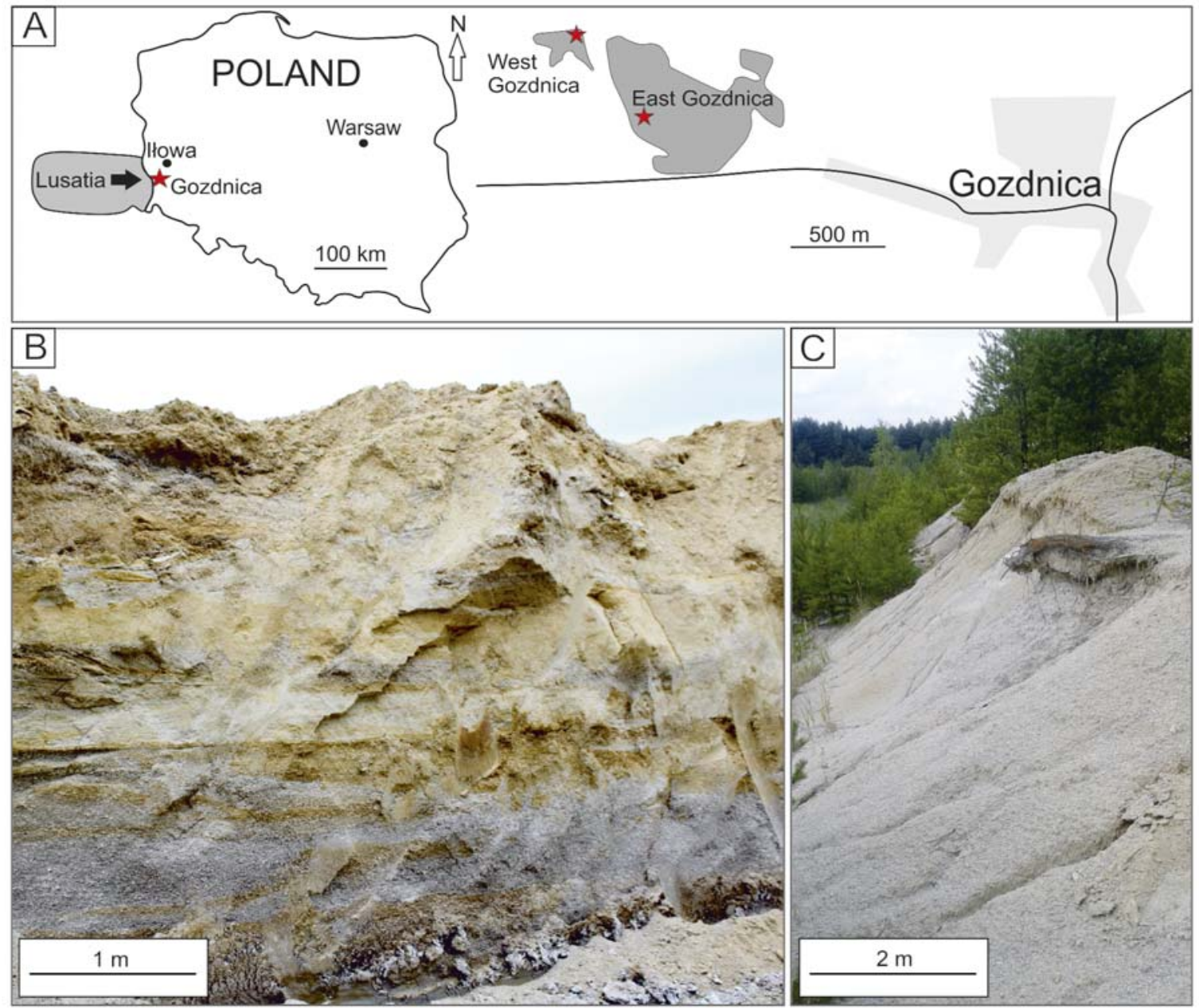

Text-fig. 1. A - Sketch-map of new moldavite finds in the East and West Gozdnica pits (SW Poland), and direction of fluvial transport of moldavites from Lusatian strewn field. B- General view of the Gozdnica Formation in the East Gozdnica sandpit. C- General view of the Gozdnica Formation in the West Gozdnica sandpit

Gozdnica pit, three tektites were collected (Text-fig. 2). Their weight varies from 0.529 to $1.196 \mathrm{~g}$. The largest moldavite is $3 \mathrm{~cm}$ long and $1 \mathrm{~cm}$ wide (Text-fig. 2A). All specimens display green bottle colour and are complete. Only one tektite (Text-fig. 2B) reveals slight corrosion marks. Two tektites are elongated, that is typical for the autochthonous material. Moldavites contain bubbles, which are spherical in shape; their diameters vary from 10 to $250 \mu \mathrm{m}$ (Text-fig. $3 \mathrm{~A}$ ). One tektite (Text-fig. 2A) contains a bubble that is $9 \mathrm{~mm}$ long, which is the largest bubble observed among Polish moldavites.

In the BSE images, many lechatelierite inclusions were noted (Text-fig. 3B). Their length varies from 20 to $300 \mu \mathrm{m}$. The single moldavite from the West Gozdnica pit weights $0.685 \mathrm{~g}$ (Text-fig. 2D, Table 1). The largest bubble in its glass is up to $4 \mathrm{~mm}$ long. From among all the new moldavites, this specimen contains the most numerous and irregular lechatelierite inclusions (Text-fig. 3B).
No other mineral inclusions were detected. The most typical features of the studied moldavites are listed in Table 1. EMP data show that the new Pol-

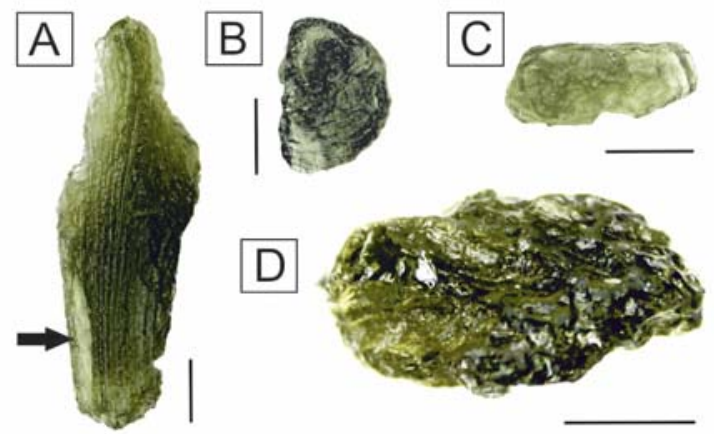

Text-fig. 2. New Polish moldavites from the Eastern (A-C) and Western (D) Gozdnica pit mines. The biggest bubble, on specimen A, is arrowed. A - sample EG1, B - sample EG2, C - sample EG3, D - sample WG1. See Table 1 for characteristics set. Scale bars are $5 \mathrm{~mm}$ 

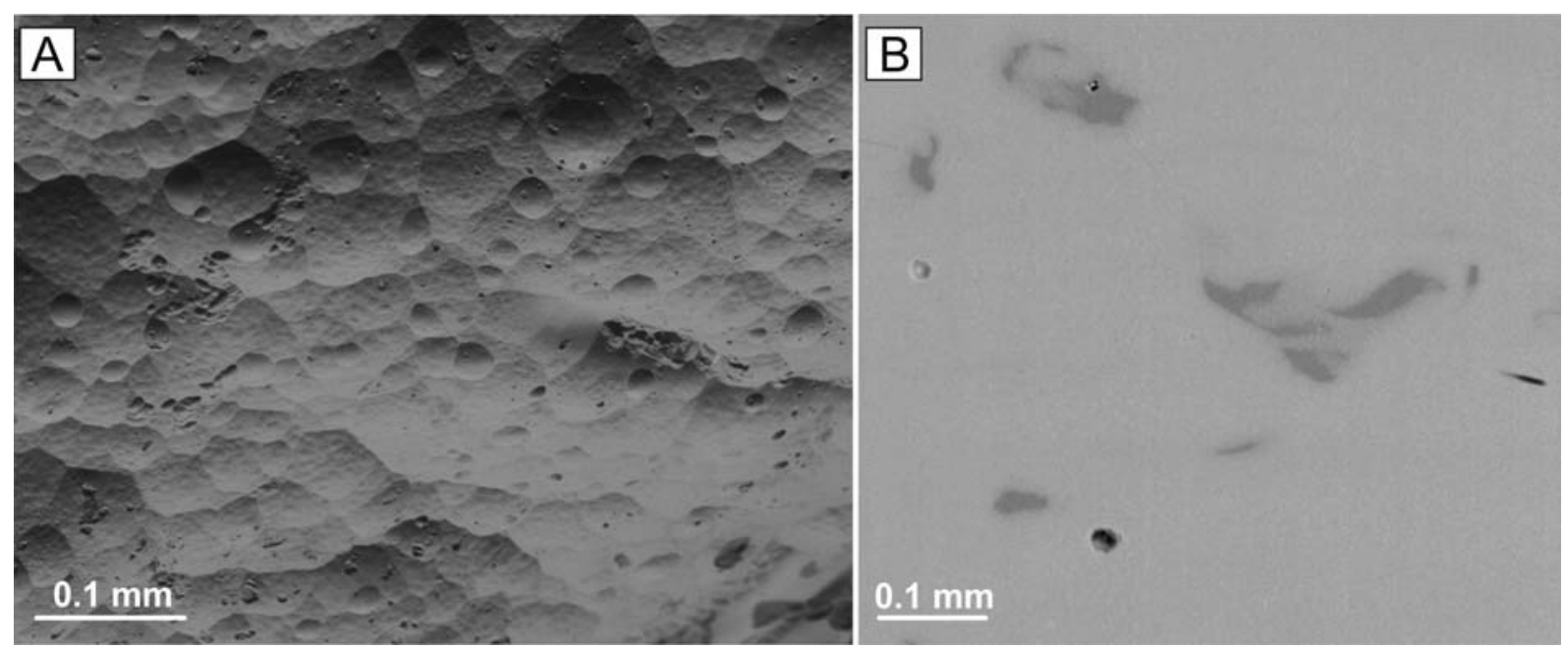

Text-fig. 3. BSE images of selected features. A - Corroded surface of the moldavite from Gozdnica (sample EG2) with bubbles is visible. B - Irregular lechatelierite inclusions in sample WG1

\begin{tabular}{|l|l|l|l|l|l|}
\hline Sample & Mass $(\mathrm{g})$ & Shape & Surface & Colour & Features \\
\hline EG1 & 1.196 & elongated & low corrosion & bottle green & $\mathrm{B} * * \mathrm{~L}^{* *}$ \\
\hline EG2 & 0.546 & ellipsoidal & corroded & bottle green & $\mathrm{B} * * * \mathrm{~L} *$ \\
\hline EG3 & 0.529 & elongated & low corrosion & bottle green & $\mathrm{B} * \mathrm{~L}^{* *}$ \\
\hline WG1 & 0.685 & elongated & low corrosion & bottle green & $\mathrm{B} * * \mathrm{~L}^{* * *}$ \\
\hline
\end{tabular}

Table 1.Characteristics of Polish moldavites (see Text-fig. 2). EG - East Gozdnica; WG - West Gozdnica; B - bubbles; L - lechatelierite; * - low rich, ** - rich, *** - very rich

\begin{tabular}{|c|c|c|c|c|c|}
\hline \multirow{2}{*}{$\begin{array}{c}\text { Element } \\
(w t . \%)\end{array}$} & \multicolumn{5}{|c|}{ Localization } \\
\cline { 2 - 6 } & East Gozdnica pit* & Mielęcin pit* & North Stanisław pit* & East Gozdnica pit** & West Gozdnica** \\
\cline { 2 - 6 } & $\mathrm{n}=12$ & $\mathrm{n}=8$ & $\mathrm{n}=10$ & $\mathrm{n}=14$ & $\mathrm{n}=10$ \\
\hline $\mathrm{SiO}_{2}$ & 76.28 & 78.31 & 76.28 & 77.34 & 78.46 \\
\hline $\mathrm{TiO}_{2}$ & 0.31 & 0.27 & 0.12 & 0.24 & 0.29 \\
\hline $\mathrm{Al}_{2} \mathrm{O}_{3}$ & 10.52 & 11.01 & 10.87 & 10.71 & 10.63 \\
\hline $\mathrm{FeO}_{\text {total }}$ & 1.98 & 1.89 & 1.92 & 1.88 & 1.82 \\
\hline $\mathrm{MnO}$ & 0.02 & 0.01 & 0.02 & 0.04 & 0.02 \\
\hline $\mathrm{MgO}$ & 1.8 & 1.78 & 1.75 & 1.75 & 1.72 \\
\hline $\mathrm{CaO}$ & 2.1 & 2.08 & 2.12 & 2.2 & 2.04 \\
\hline $\mathrm{Na}_{2} \mathrm{O}$ & 0.51 & 0.51 & 0.57 & 0.49 & 0.55 \\
\hline $\mathrm{K}_{2} \mathrm{O}$ & 3.6 & 3.58 & 3.21 & 3.36 & 3.28 \\
\hline $\mathrm{P}_{2} \mathrm{O}_{5}$ & 0.04 & 0.05 & 0.07 & 0.05 & 0.03 \\
\hline $\mathrm{TOTAL}$ & 97.16 & 99.49 & 96.93 & 98.06 & 98.84 \\
\hline
\end{tabular}

Table 2. Average chemical composition of moldavites from Poland, based on EMP (average wt $\%$ from n samples); * data from Brachaniec et al. (2015), $* *$ this study

ish moldavites are characterized by $\mathrm{SiO}_{2}$ content ranging from 77.34 to $78.46 \mathrm{wt} \%$ which is slightly higher than moldavites from other Polish sections (Brachaniec et al. 2015). The content of other main elements $(\mathrm{Al}, \mathrm{Fe}, \mathrm{Mg}, \mathrm{Ca})$ is similar in all speci- mens. The chemical variation of investigated tektites falls in the range of all known moldavites, as described by Trnka and Houzar (2002). The chemical composition of investigated moldavites is presented in Table 2. 


\section{DISCUSSION}

\section{Origin of the Polish moldavites}

According to Brachaniec et al. $(2014,2015)$ Polish moldavites are parautochthonous. They were found in fluvial sediments, c. $10 \mathrm{Ma}$ in age (Szynkiewicz 2011), whereas the Ries event is dated as c. $14.8 \mathrm{Ma}$ (Buchner et al. 2013). The large size and evidence of only minor corrosion are indicative of rather short transport. It seems that moldavites described in this paper confirm this hypothesis. Investigated tektites from two sections near Gozdnica are similar in size to those found in 2014. In contrast, much smaller specimens $(0.003-0.15 \mathrm{~g})$ were noted in the North Stanisław and Mielęcin pits (Brachaniec et al. 2014, 2015). Additionally, the degree of corrosion is similar. In our opinion, a characteristic elongated moldavite with non-eroded edges could not have been transported over long distance. Probably, it was associated with small quantity of gravel, content of which increases to the east. Parautochthonous origin of material is also confirmed by chaotic distribution in sediments because the Czech autochthonous tektites occur in well-defined moldavite horizonts. According to Žebera (1972) and Bouška et al. (1999) the moldavites outside the main strewn fields constitute redeposited material. The mechanism of moldavite fluvial reworking over a distance of a tenth of a kilometre is known from the Czech strewn field (Bouška 1964) and Lusatia (Lange 1996). Fluvial redeposition has also shaped a tektite glass (see discussion in Trnka and Houzar 2002). The only possible source area of Polish moldavites is the Lusatian region, from where large rivers were flowing eastward (Badura and Przybylski 2004). In the Late Miocene, the Sudetes were uplifted, which effectively limited the river-flow from the south. Additionally, the area of the Fore-Sudetic Block, north of the mountains (Grocholski 1977; Kural 1979), contained numerous depressions and meanders, where accumulation of sands, gravel and clays took place. The Gozdnica Formation originated on the Sudetic Foreland as alluvial deposits during the Pannonian (Piwocki and Ziembińska-Tworzydło 1997). These sediments were deposited before the first Scandinavian ice-sheet advanced onto the older fluvial lacustrine-marine deposits of the Poznań Formation (Badura and Przybylski 2004). They represent most probably the distal alluvial cone of pre-Nysa Łużycka river (Dyjor et al. 1992, 1998).

\section{Bubbles and lechatelierite}

The Polish moldavites contain numerous bubbles and inclusions of lechatelierite and the surfaces of investigated tektites are slightly corroded. This is indicative of a short transport and redeposition but also rules out extensive interaction with humic substances in the soil, which rapidly destroys glass surfaces (Koeberl et al. 1988). According to Suess (1951) and Chao (1963) the bubbles are a result of internal gas pressure during tektite cooling in environment where the external pressure was very low. Elongated bubbles, such as inclusions of lechatelierite in glass, correspond to the direction of flow in tektite melts. In glass, several mechanisms of bubble formation may be involved. A single tektite sample may contain several populations of bubbles formed by different mechanisms and containing gases of different compositions and pressures (Jessberger and Gentner 1972; see also discussion by Žak et al. 2012).

The lechatelierite forms as a result of melting of a terrestrial quartz grains in a high pressure during impact, and allows to distinguish between an impact glass and a terrestrial volcanic glass. The temperature necessary to lechatelierite formation is above $1713^{\circ} \mathrm{C}$ (Stöffler (1984), that is far above the normal terrestrial igneous processes. The elongated inclusions of the lechatelierite observed in investigated tektites are indicative of rapid and irregular glass flow during an early formation stage (Koeberl et al. 1988). The amount of lechatelierite depends on the temperature conditions of origin. Higher temperature caused a lower abundance of lechatelierite in the Czech and German moldavites (Barnes 1969; Lange 1995). Lechatelierite in moldavites is represented by almost pure silica, consistent with previous studies by Knobloch (1997) and Brachaniec et al. (2015). Other mineral inclusions are not present in the samples.

\section{Chemical composition}

The chemical composition of all impact glasses including tektites is a result of melting and sometimes mixing of molten source rocks (Magna et al. 2011). The moldavites are the most acidic group of tektites, with $\mathrm{SiO}_{2}$ contents c. $80 \mathrm{wt} \%$ (Engelhardt et al. 1987; Trnka and Houzar 2002). EMPA data show (Table 2) that the investigated moldavites have relatively high content of $\mathrm{SiO}_{2}$ and low content of $\mathrm{Fe}$. The moldavites from Lusatia have in average higher $\mathrm{SiO}_{2}$ content $(79.3 \mathrm{wt} \%)$ than Polish specimens but the concentrations of other main elements ( $\mathrm{Al}, \mathrm{Fe}, \mathrm{Mg}, \mathrm{Ca}$ ) is similar with only minor differences (see details in Lange 1995). In summary, it is possible that Polish and Lusatian moldavites, despite the fact that they come from the same strewn field, could have formed from lithologically different parts of the Upper Freshwater Molasse. According to Engelhardt et al. (2005) and Ǩanda et al. (2008), the similarity of the major element contents in tektite glasses indicates very similar, but nit necessarily identical source deposits. The Upper Freshwater Molasse, the source of 
moldavites, contain many lenses of carbonates and clays, which may account for the observed changes in moldavite compositions. Ǩanda et al. (2008) claimed that tektites with similar $\mathrm{Mg}$ and $\mathrm{Ca}$ contents are evidence of a carbonate origin, whereas high content of $\mathrm{Al}$ originates form clay components. Based on average chemical composition, it may be tentatively suggested that the Polish parautochthonous moldavites were formed from quartz sands with a slightly higher content of carbonates and clays than autochthonous specimens from Lusatia. The chemical composition (EMPA) of the moldavites and the total sum of measured features (\%wt. oxides; that is changing from $\sim 97.5$ to $\sim 99.5$ ) might indicate that the potential water content in the studied moldavites is up to $2.0 \%$.

\section{CONCLUSIONS}

Although experimental data indicate the probability of tektite occurences c. $500 \mathrm{~km}$ from the Ries crater (Stöffler et al. 2002), Polish autochthonous moldavites have not been detected yet. Characteristic features for tektites, such as bubbles and lechatelierite inclusions, confirm their impact origin. The sedimentary characteristics of the Gozdnica Formation and the Middle/Late Miocene palaeogeography of the studied area, clearly suggest the fluvial transport of Polish tektites from the Lusatian strewn field. Low degree of corrosion confirms short transport of the investigated glass.

\section{Acknowledgments}

This project is financially supported by NCN grant no. 2014/13/N/ST10/04921.The authors thank Prof. Andrzej Muszyński (Adam Mickiewicz University in Poznań, Poland), Prof. Bruce Simonson (Oberlin College, USA) and Prof. Ireneusz Walaszczyk (University of Warsaw, Poland) who provided detailed and useful reviews of the manuscript. Prof. I. Walaszczyk is also thanked for editorial handling.

\section{REFERENCES}

Artemieva, N., Pierazzo, E. and Stöffler, D. 2002. Numerical modeling of tektite origin in oblique impacts: Implication to Ries-Moldavites strewn field. Bulletin of the Czech Geological Survey, 77, 303-311.

Baraniecka, M.D. 1991. Section Różce against main sections of preglacial deposits in southern Mazowsze. Przeglą Geologiczny, 39, 254-257. [In Polish with English summary]
Badura, J. and Przybylski, B. 2004. Evolution of the Late Neogene and Eopleistocene fluvial system in the foreland of the Sudetes Mountains (southwest Poland). Annales Societatis Geologorum Poloniae, 74, 43-61.

Baker, G. 1963. Form and sculpture of tektites. In: J.A.O'Keefe (Ed.), Tektites, III, pp. 1-24.University of Chicago Press; Chicago.

Barnes, V.E. 1969. Petrology of moldavites.GeochimicaetCosmochimicaActa, 33, 1121-1134.

Bouška, V. 1964.Geology and stratigraphy of moldavite occurrences. Geochimica et Cosmochimica Acta, 28, 921-922.

Bouška, V., Kadlec, J. and Žak, K. 1999. Moldavite aus dem westlichen und dem nordlichen Teil Bohmen. Staatliches Museum fürMineralogie und Geologie, Dresden, 10, 16-19.

Brachaniec, T., Szopa, K. and Karwowski, Ł. 2014. Discovery of the most distal Ries tektites found in Lower Silesia, southwestern Poland. Meteoritics \& Planetary Science, 49, 1315-1322.

Brachaniec, T., Szopa, K. and Karwowski, Ł. 2015. A new discovery of parautochthonous moldavites in southwestern Poland, Central Europe. Meteoritics \& Planetary Science, 50, 1697-1702.

Buchner, E. and Schmieder, M. 2009. Multiple fluvial reworking of impact ejecta-A case study from the Ries crater, southern Germany. Meteoritics \& Planetary Science, 44, 1051-1060.

Buchner, E., Schmieder, M., Schwarz, W.H. and Trieloff, M. 2013. Das Alter des Meteoriten craters Nordlinger Ries eine Übersicht und kurze Diskussion der neueren Datierungen des Ries impakts. Zeitschrift der Deutschen Gesellschaft für Geowissenschaften, 164, 433-445.

Chao, E.C.T. 1963. The petrographic and chemical characteristics of tektites.In: J.A.O'Keefe (Ed.), Tektites, III, pp. 5194.University of Chicago Press; Chicago.

Dence, M.R. 1971. Impact melts. Journal of Geophysical Research, 76, 5552-5565.

Dyjor, S., Kvacek, Z., Łańcucka-Środoniowa, M., Pyszyński, W., Sadowska, A. and Zastawniak, E. 1992.The younger Tertiary deposits in the Gozdnica region (WS Poland) in the light of recent palaeobotanical research. In: E. Zastawniak (Ed.), Polish Botanical Studies. Polish Academy of Science, 3, 1-133.

Dyjor, S., Sadowska, A., Humemel, A., Baranowska-Zarzycka, Z. and Zastawniak, E. 1998. Geological position and flora of the younger Neogene deposits in Lower Silesia. In: A. Sadowska and A. Szynkiewicz (Eds), The 5th European Palaeobotanical and Palynological Conference, pp. 37-54. Cracow.

Engelhardt, W. von 1972. Shock produced rock glasses from the Ries crater. Contributions to Mineralogy and Petrology, 36, 265-292.

Engelhardt, W. von., Luft, E., Arndt, J., Schock, H. and Weiskirchner, W. 1987. Origin of moldavites. Geochimica et Cosmochimica Acta, 51, 1425-1443. 
Engelhardt, W. von, Berthold, C., Wenzel, T. and Dehner, T. 2005.Chemistry, small-scale inhomogeneity, and formation of moldavites as condensates from sands vaporized by the Ries impact. Geochimica et Cosmochimica Acta, 69, 56115626.

Glass, B.P. and Simonson, B.M. 2013. Distal impact ejecta layers.A record of large impacts in sedimentary deposits, pp. 1716. Springer; Berlin - Heidelberg.

Grocholski, A. 1977.The marginal Sudetic fault against the Tertiary volcanotectonics. Prace Geologiczno-Mineralogiczne, 6, 89-103.

Jessberger, E. and Gentner, W. 1972. Mass spectrometric analysis of gas inclusions in Muong Nong glass and Libyan Desert Glass. Earth and Planetary Science Letters, 14, 221-225.

Knobloch, V. 1997. Nektere problemv zniku vltavinu III. Tvary inkluzi a textura ve svetle impaktoveho procesu, Přirodovědnýsborník Západomoravského muzea v Třebičí, 31, 54-60.

Knobloch, V., Knoblochová Z. and Urbanec, Z. 1981.Beitragzur Morphologie von Lechatelierit in Moldaviten.Chemie derErde, 40, 83-95.

Knobloch, V., Knoblochová, Z. and Urbanec, Z. 1983. Struktur und Textur von Lechatelieriteinschlussen und ihre Beziehungen zur Morphologie der Moldavite. Chemie der Erde, 42, $145-154$.

Koeberl, C. 2007. The geochemistry and cosmochemistry of impacts. In: H.D. Holland and K.K. Turekian (Eds), Meteorites, comets, and planets, pp. 1-52. Elsevier; Oxford.

Koeberl, C., Brandstätter, F., Niedemmazr, G. and Kurat, G. 1988. Moldavites from Austria. Meteoritics, 23, 325-332.

Kural, S. 1979. Origin, age and geologic background of the kaolin in the western part of the Strzegom. Biuletyn Instytutu Geologicznego, 313, 9-68.

Lange, J.M. 1995. Lausitzer Moldavite und ihre Fundschichten, pp. 1-134. Schriften für Geowissenschaften 3; Berlin.

Lange J.-M. 1996. Tektite glasses from Lusatia (Lausitz), Germany. Chemie der Erde, 56, 498-510.

Magna, T., Deutsch, A., Mezger, K., Skála, R., Seitz, H.M., Mizera, J., Řanda, Z. and Adolph, L. 2011. Lithium in tektites and impact glasses: Implications for sources, histories and large impacts. Geochimica et Cosmochimica Acta, 75, 2137-2158.

Meisel, T., Lange, J.-M.andKrahenbuhl, U. 1997. The chemical variation of moldavite tektites: Simple mixing of terrestrial sediments. Meteoritics \& Planetary Science, 32, 493-502.

Osinski, G.R. 2003. Impact glasses in fallout suevites from the Ries impact structure, Germany: An analytical SEM study. Meteoritics \& Planetary Science, 38, 1641-1667.

Piwocki, M. and Ziembińska-Tworzydło, M. 1997. Neogene of the Polish Lowlands - lithostratigraphy and pollen-spore zones. Geological Quarterly, 41, 21-40.

Piwocki, M., Badura, J. and Przybylski, B. 2004. Neogen: miocen, pliocen. In: T. Peryt and M. Piwocki (Eds), Geologia Polski, 1, 71-201. Państwowy Instytut Geologiczny; Warszwa.

Řanda, Z., Mizera, J., Frána, J. and Kučera, J. 2008. Geochemical characterization of moldavites from a new locality, the Cheb Basin, Czech Republic. Meteoritics \& Planetary Science, 43, 461-477.

Sadowska, A. 1992. A palynological study of the profiles from Gozdnica and Gozdnica-Stanislaw localities. In: E. Zastawniak (Ed.), The younger Tertiary deposits in the Gozdnica region (SW Poland) in the light of recent palaeobotanical research. Polish Botanical Studies, 3, 11-17.

Skála, R. and Čada, M. 2003. Major element composition of three moldavites from Dřenice, the Cheb Basin, Czech Republic. Acta Scientiarum Naturalium Musei Moraviae Occidentalis Třebíč, 41, 11-17.

Stachurska, A., Dyjor, S., Kordysz, M. and Sadowska, A. 1971. Paleobotanic characteristics of Late Tertiary sediments at Gozdnica (Lower Silesia). Annales de la Société géologique de Pologne, 41, 359-386. [In Polish with English summary]

Stöffler, D. 1984. Glasses formed by hypervelocity impact. Journal of Non-Crystalline Solids, 67, 465-502.

Stöffler, D., Artemieva, N.A. and Pierazzo, E. 2002. Modeling the Ries-Steinheim impact event and the formation of the moldavite strewn field. Meteoritics \& Planetary Science, 37, 1893-1907.

Suess, H.E. 1951. Gas content and age of tektites. Geochimica et Cosmochimica Acta, 2, 76-79.

Szynkiewicz, A. 2011. Wiek utworów neogenu w Zachodniej części Dolnego Śląska. In: A. Żelaźniewicz, J. Wojewoda and W. Ciężkowski (Eds), Mezozoik i kenozoik Dolnego Śląska, pp. 11-18.WIND.

Trnka, M. and Houzar, S. 2002. Moldavites: a review. Bulletin of the Czech Geological Survey, 77, 283-302.

Žák, K., Skála, R., Řanda, Z. and Mizera, J. 2012. A review of volatile compounds in tektites, and carbon content and isotopic composition of moldavite glass. Meteoritics \& Planetary Science, 47, 1010-1028.

Žebera, K. 1972. Vltaviny v katastrofalnich přivalovych sedimentech u Prahy. Geologicky Průzkum, 14, 54-56.

Żelaźniewicz, A., Wojewoda, J. and Ciężkowski W. 2011. Przewodnik do wycieczek LXXXI Zjazdu Polskiego Towarzystwa Geologicznego. pp. 1-72. Polskie Towarzystwo Geologiczne; Wrocław. 